\title{
RECENT RELATIVE VERTICAL MOVEMENTS IN THE TECTONIC ZONE OF THE SUDETY MTS.
}

\author{
Adrian KACZMAREK ${ }^{1)}$, Stefan CACOŃ ${ }^{1) *}$ and Josef WEIGEL ${ }^{2)}$ \\ 1) Wroclaw University of Environmental and Life Sciences, Institute of Geodesy and Geoinformatics, ul. Grunwaldzka 53, \\ 50-357 Wroclaw, Poland \\ 2) Brno University of Technology, Faculty of Civil Engineering, Institute of Geodesy, Veveři 95, 60200 Brno, Czech Republic
}

*Corresponding author's e-mail: stefan.cacon@igig.up.wroc.pl

\begin{tabular}{l} 
ARTICLE INFO \\
\hline Article history: \\
Received 9 February 2015 \\
Accepted 25 November 2015 \\
Available online 15 December 2015 \\
\hline
\end{tabular}

Keywords:

The Sudety Mts.

Tectonic fault

Precise levelling

Relative vertical movements

\begin{abstract}
Recent geodynamic activity of the Sudeten in the area of Poland and the Czech Republic has been confirmed by the results of geodynamic, seismic, geodetic and other tests. This is especially the case for the periodical (the last 25 years) satellite GPS/GNSS and gravimetric measurements in the regional research network GEOSUD, SILESIA, SUDETY and the local geodynamic polygons ("Snieznik", "Stolowe Mts."), as well as observation of crack-gauges on several tectonic faults. Vertical movements are indicated in the maps of recent movements of the Earth's crust. Two adjacent countries in the area of the Sudeten achieved results from $+0.5 \mathrm{~mm} /$ year to $-2 \mathrm{~mm} /$ year with reference to the tide gauge on the coast of the Baltic Sea. They present absolute value received on the basis of a comparison of the results of repeated (in intervals of 2030 years) measurements of $1^{\text {st }}$ order levelling lines. The characteristics of this data do not allow for an assessment of recent tectonic activity in the Sudety Mts. because the isolines of absolute velocities of vertical movements of the Earth's crust surface on the maps (Wyrzykowski, 1985; Kowalczyk, 2006; Vyskočil, 2002) present "smoothed" large-area changes without a proof of dynamic changes in the Sudeten tectonic zones.

This paper presents results of analysis archival data on repeated measurement precise levelling networks. The results of analysis were used to produce maps of vertical movements of the Earth's crust surface. Analysis is focused on the part of levelling lines which intersect Sudeten main tectonic faults. This paper included methodology of data processing. In research period relative vertical movements of tectonic zones are referencing to the relative stable benchmark. The values of these velocities between $-0.8 \div+0.8 \mathrm{~mm} /$ year confirm recent geodynamic mobility in this Central European area.
\end{abstract}

\section{INTRODUCTION}

The geological structure of the Sudety Mts. having the nature of a block is defined as a mosaic because of the large variety of rocks and numerous dislocations separating tectonic units of different ages and structure (Stupnicka, 2007). Recent seismic activity in this area is confirmed by the size of the earthquakes as $5.5^{\circ} \mathrm{MSK}$, observed in the area of Jilovice Fault (Procházková, 1989), in the tectonic zone Poříćí-Hronov (Zedník et al., 2001) and the active tectonic region Hrubý - Jeseník (Jechumtálová and Š́lený, 2014).

The geodetic and geological research in the Sudety Mts. based on the periodical GPS measurement in the last quarter of the 20th century showed horizontal movement slip of the main tectonic zone of the Sudety Mts. and Fore-Sudetic block (Cacoń et al., 2004, 2010; Kapłon and Cacoń, 2009; Kapłon et al., 2014; Kontny, 2003; Schenk et al., 2003). These same GPS measurements showed no significant changes of vertical movements of these tectonic zones because results of GPS measurement (vertical component - absolute height) are not determined with high precision. The vertical movements of the Earth's crust surface in the Sudety
Mts. area are confirmed by repeated measurements of basic levelling lines, $1^{\text {st }}$ and $2^{\text {nd }}$ order, which include the period of the last 50 years of the 20th century (Wyrzykowski, 1985; Kowalczyk, 2006; Vanko and Vyskočil, 1987; Vyskočil, 2002). Figures 1, 2 and 3 show the isolines of velocities of vertical movements of the Earth's crust surface in the Sudety Mts. as maps encompassing the area of Poland and the Czech Republic. Wyrzykowski (1985) showed on the map (Fig.1) the results based on measurement on Polish levelling networks in the years 1952-1956 and 19751977. Kowalczyk's (2006) results are showed in Figure 2, including measurements of the same networks in 1975-1977 and 1997-2003. In Figure 3 Vyskočil (2002) showed isolines of velocities of vertical movements of the Earth's crust surface in the area of Karkonosze-Jeseniky based on measurements on Czech levelling networks in the years 1960-1973 and after 1990 for selected levelling lines. Measurements of these levelling networks performed after 1990 for selected levelling lines have not yet been included in this study. It should be noted that graphic image changes of the Earth's crust surface presented in three figures, although they are not complementary on both sides of the Polish-Czech 


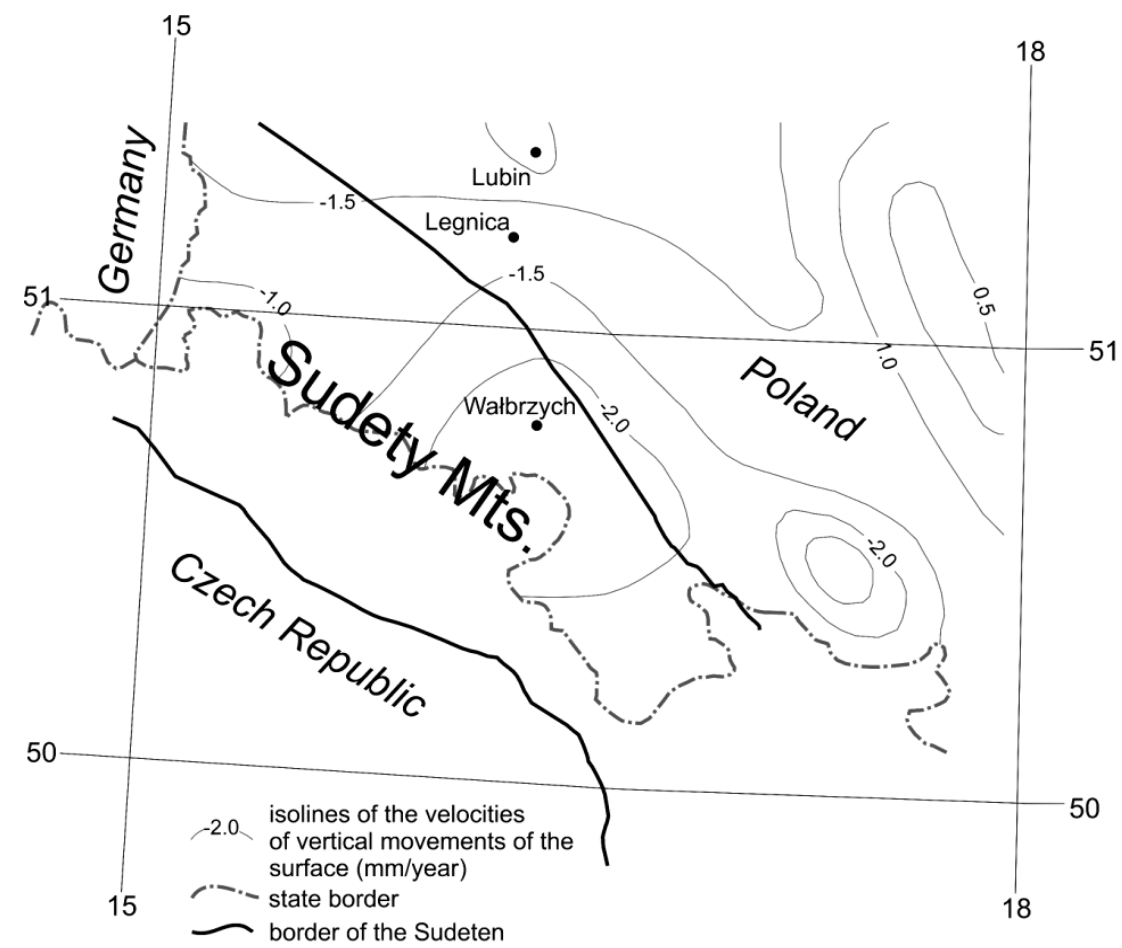

Fig. 1 The part of map velocities of vertical movements of the Earth's crust surface in the area of Poland (study based on (Wyrzykowski, 1985)).

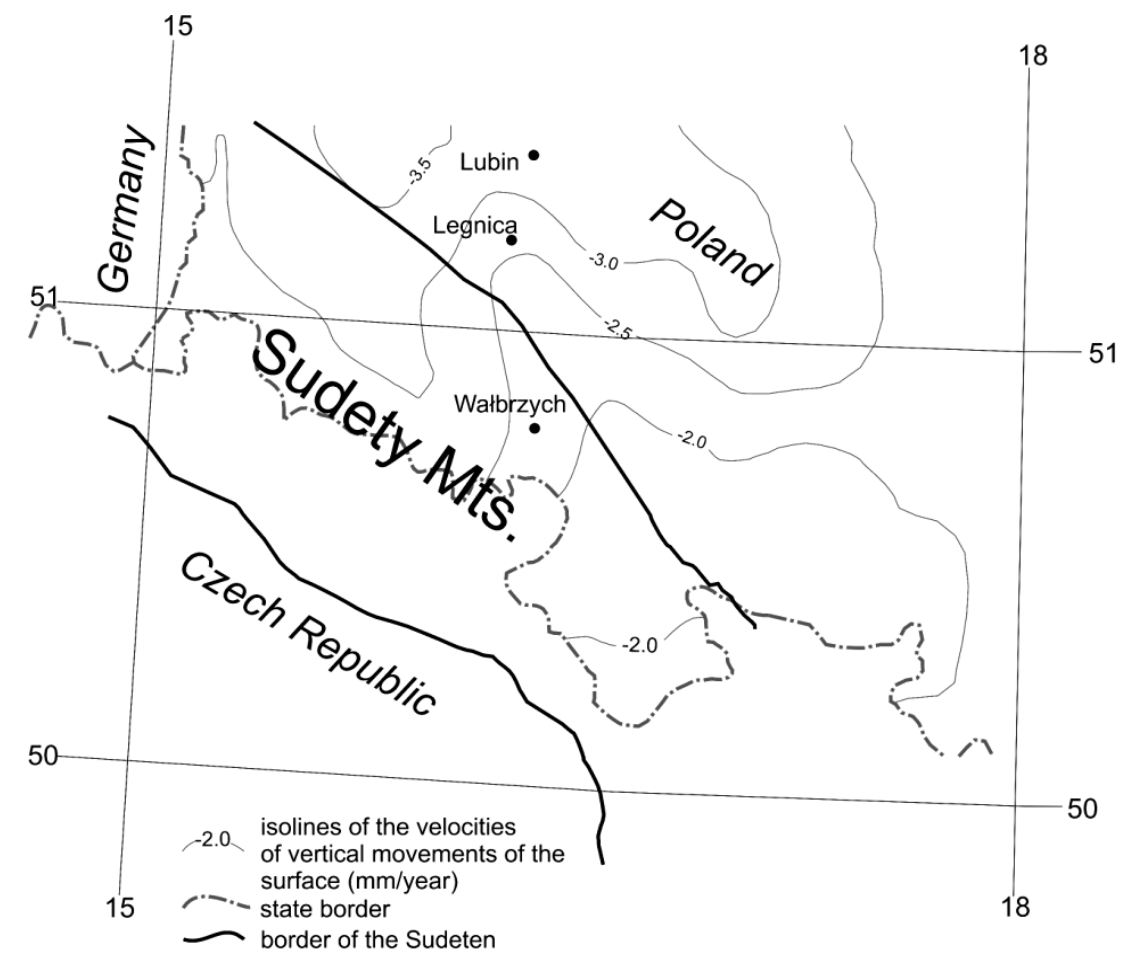

Fig. 2 The part of map velocities of vertical movements of the Earth's crust surface in the area of Poland (study based on (Kowalczyk, 2006)). 


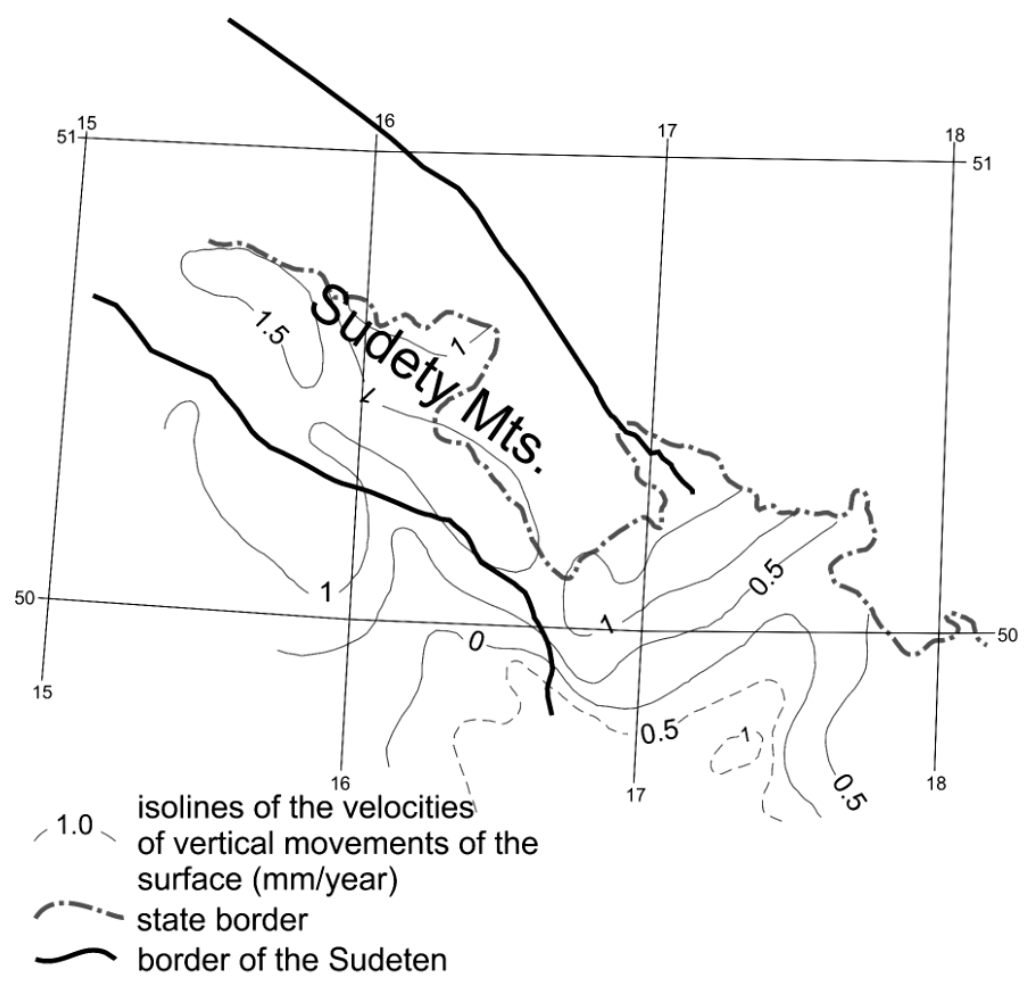

Fig. 3 The part of map velocities of vertical movements of the Earth's crust surface in the area of the Czech Republic (study based on (Vyskočil, 2002)).

border in the Sudety Mts., confirm the theory of recent mobile geological structure of this area. The results of this research intend to describe relative changes in movements of blocks of rocks on their borders in coincidence with the main tectonic faults. Due to the limited number of levelling lines (possible to use) and intersecting these tectonic faults, it is impossible to investigate all blocks of rock extracted in the geological research.

\section{METHODOLOGY}

The calculations contained only these levelling lines, which were measured in at least two measurement epochs (Fig. 4). The archival data contained sets of height differences between benchmarks in research period. They were the basis for determining the relative stable reference benchmark in each line. The calculations were carried out according to the formulae in (Wyrzykowski, 1993).

The first step involved calculating the root mean square error (RMSE) of height differences of the analysed levelling section $\left(m_{\Delta h_{i}}\right)$ :

$m_{\Delta h_{i}}= \pm m_{0} \cdot \sqrt{R_{i}}$

where:

$m_{0}-$ RMSE of $1 \mathrm{~km}[\mathrm{~mm}],\left(1^{\text {st }}\right.$ order lines $1 \mathrm{~mm}, 2^{\text {nd }}$ order lines $2 \mathrm{~mm}$ )

$R_{i}$ - length of section between two benchmarks [km].
Then the height difference change between measurement epochs $\left(r_{t}\right)$ was calculated for each section:

$r_{i}=\Delta h_{i}^{I I}-\Delta h_{i}^{I}$

where:

$\Delta h_{i}^{I I} ; \Delta h_{i}^{I}$ - height differences respectively for the two measurement epochs.

The next step was determination of RMSE of height difference change $r_{i}$ :

$m_{r_{i}}= \pm m_{\Delta h_{i}} \cdot \sqrt{2}$

In the next step the stability of benchmarks was determined separately for each part of the levelling line. The relative stable benchmark must satisfy the condition that the height difference change $\left(r_{i}\right)$ between measurement epochs could not exceed (at the significance level $\alpha=0.05)$ the "double error" = two times $\left(m_{r_{i}}\right)$

$r_{i} \leq 2 \cdot m_{r_{i}}$

The specified relative stable reference point is the basis for calculating the height benchmarks $\left(H_{I} ; H_{I I}\right)$ for which the RMSE $\left(m_{\Delta H_{i}}\right)$ are calculated on the basis of:

$m_{\Delta H_{i}}= \pm m_{0} \cdot \sqrt{2 L_{i}}$ 


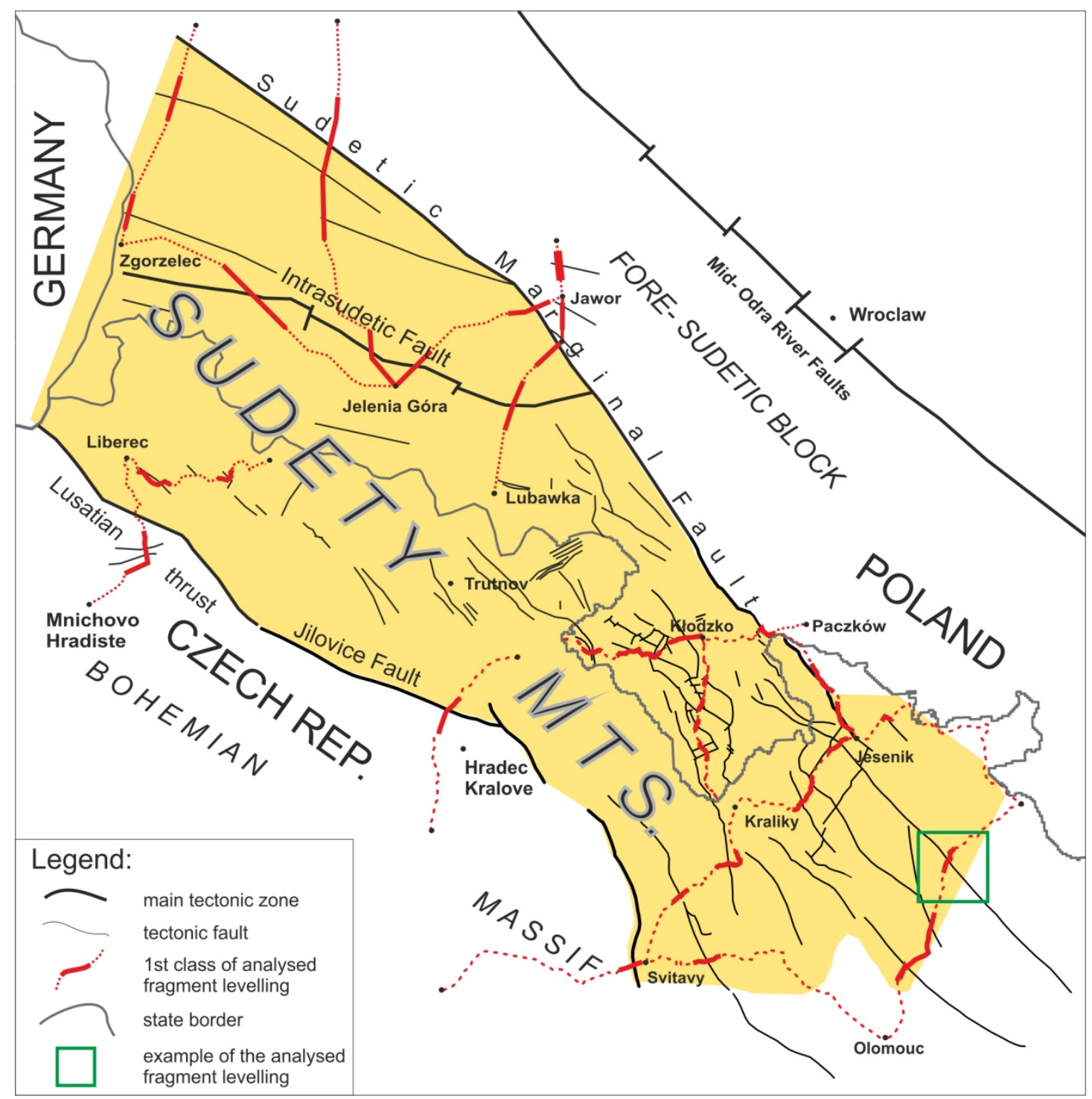

Fig. 4 Levelling lines in the part of Poland and the Czech Republic.

where:

$2 L_{i}$ - double length between the benchmark set and relative stable benchmark $[\mathrm{km}]$.

To standardize the results of this analysis velocities of height change $\left(V_{\Delta H_{i}}\right)$ of analysed benchmarks were calculated according to the formula:

$V_{\Delta H_{i}}=\frac{H_{I I}-H_{I}}{t_{I I}-t_{I}}$

where:

$t_{I I} ; t_{I}$ - year of measurement respectively for the two epoch of measurements

The root-mean-square error of height change velocities for individual benchmarks are calculated using the formula:

$m_{V_{\Delta H_{i}}}= \pm \sqrt{\frac{2 \cdot m_{0}^{2} \cdot L_{i}}{\left(t_{I I}-t_{I}\right)^{2}}}$
Significant displacement was detected using criterion given by the formulae (4) and (5).

Course of action with the use of the above formulae the relative changes of height benchmarks were calculated. Selected parts of levelling lines used in this paper are shown in Figure 4.

\section{EXAMPLE OF THE ANALYSES}

Figure 4 presents the state levelling networks that are located in the area of Poland and the Czech Republic. These fragments are marked on the analysed levelling lines.

The repeated precision levelling data of the Polish territory were measured in campaigns: II (1952-1956), III (1975-1977) and IV (1997-2003). The levelling data for the Czech Republic were measured in years 1940-48 and 1975. The archival data in this analysis include results of field measurements based on repeated 1st order precise 


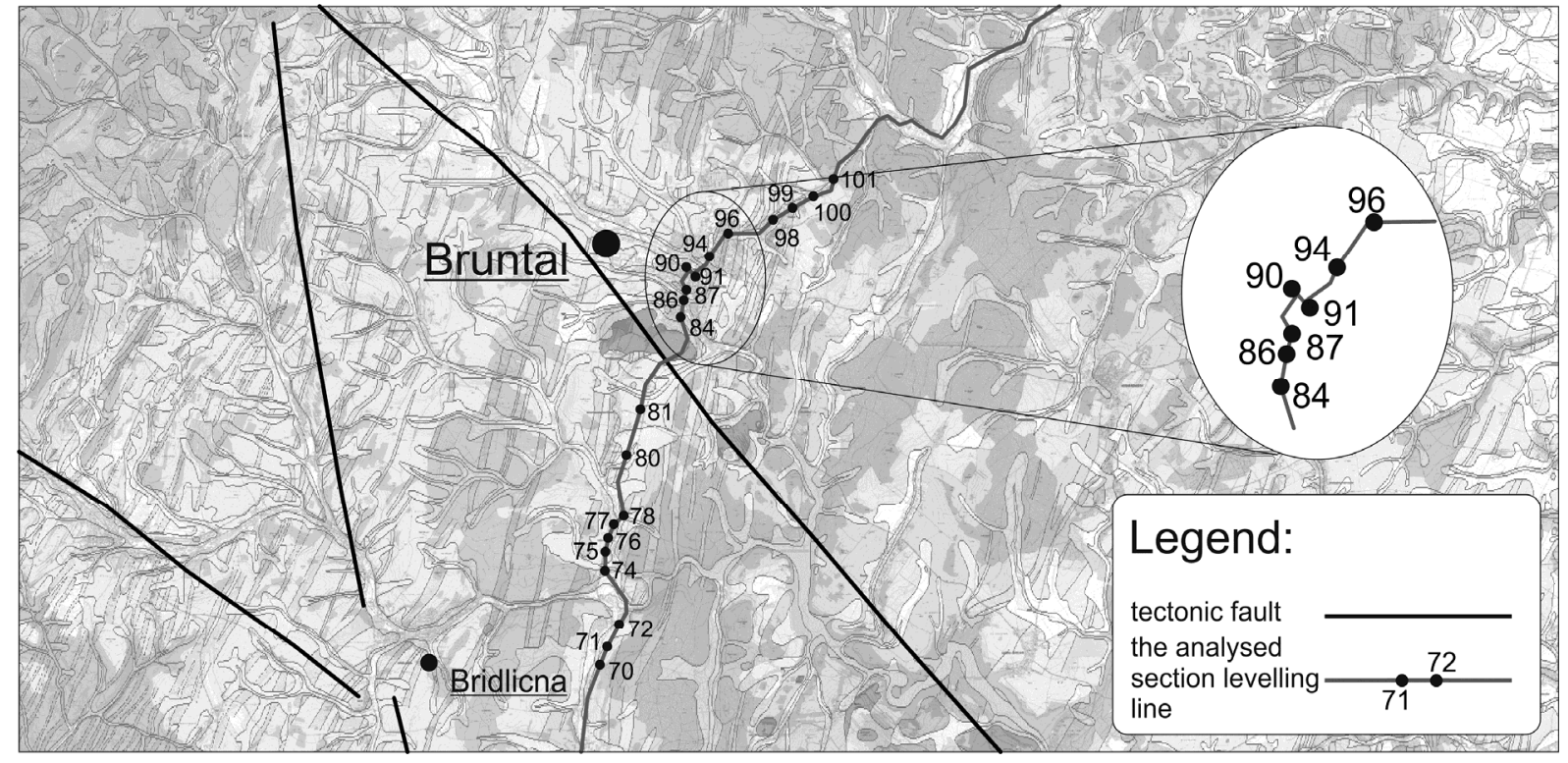

Fig. 5 Example of analysed fragment of the levelling line (Czech Republic).

levelling, which accuracy was determined on level $\mathrm{m}_{0}=1 \mathrm{~mm} / \mathrm{km}$ in order to unify heterogeneous data in the area of the Sudety Mts. (Polish and the Czech Republic). The data structure for the vertical movement calculation includes height differences between the benchmarks taking into account comparation and temperature corrections for rods. These analyses were performed for fragments of levelling line (Fig. 4) based on principles, which were presented in section "Methodology". Results of these analyses are shown on example of the Czech levelling line part (Fig. 5). This line has been measured in 1948 and 1975. Quantitative data are shown in Tables 1 and 2.

The analysed part of the levelling line consists of 21 benchmarks that intersect the tectonic fault.

Table 1 Determination of relative constant reference benchmark for the analysed part of the levelling line.

\begin{tabular}{|c|c|c|c|c|c|c|c|c|}
\hline \multicolumn{2}{|c|}{ Benchmarks } & \multirow{2}{*}{$\begin{array}{l}\text { Length } \\
\text { of } \\
\text { section } \\
{[\mathrm{km}]}\end{array}$} & \multicolumn{2}{|c|}{$\begin{array}{c}\text { Height difference } \Delta h[\mathrm{~m}] \\
\text { Epoch of measurement }\end{array}$} & \multirow{2}{*}{$\begin{array}{c}\text { Height } \\
\text { difference } \\
\text { change } \\
r[\mathrm{~mm}]\end{array}$} & \multirow{2}{*}{$\begin{array}{l}\text { RMSE height } \\
\text { difference } \\
\text { change } \\
\text { [mm] }\end{array}$} & \multirow{2}{*}{$\begin{array}{c}\text { Double error } \\
\text { of difference } \\
\text { change } \\
\text { [mm] }\end{array}$} & \multirow{2}{*}{$\begin{array}{c}\text { Condition } \\
r \leq\left|m_{r}\right| \\
\text { (stable } \\
\text { point } \\
\text { "+") }\end{array}$} \\
\hline from & to & & 1948 & 1975 & & & & \\
\hline 70 & 71 & 0.47 & -2.92554 & -2.91799 & 7.55 & 0.69 & 1.94 & \\
\hline 71 & 72 & 0.61 & -22.23039 & -22.22924 & 1.15 & 0.78 & 2.21 & + \\
\hline 72 & 74 & 1.80 & -5.56178 & -5.56337 & -1.59 & 1.34 & 3.79 & + \\
\hline 74 & 75 & 0.56 & 2.39008 & 2.38889 & -1.19 & 0.75 & 2.11 & + \\
\hline 75 & 76 & 0.34 & -0.94446 & -0.94762 & -3.16 & 0.58 & 1.65 & \\
\hline 76 & 77 & 0.48 & -1.16046 & -1.16158 & -1.12 & 0.69 & 1.96 & + \\
\hline 77 & 78 & 0.33 & -2.61260 & -2.60582 & 6.78 & 0.58 & 1.63 & \\
\hline 78 & 80 & 1.61 & 20.99866 & 21.00151 & 2.85 & 1.27 & 3.59 & + \\
\hline 80 & 81 & 1.14 & 13.15458 & 13.15994 & 5.36 & 1.07 & 3.02 & \\
\hline 81 & 84 & 2.70 & -19.52932 & -19.53064 & -1.32 & 1.64 & 4.65 & + \\
\hline 84 & 86 & 0.46 & -5.24099 & -5.23985 & 1.14 & 0.68 & 1.92 & + \\
\hline 86 & 87 & 0.26 & 5.85923 & 5.85784 & -1.39 & 0.51 & 1.44 & + \\
\hline 87 & 90 & 0.56 & 8.96982 & 8.97348 & 3.66 & 0.75 & 2.12 & + \\
\hline 90 & 91 & 0.16 & 1.34450 & 1.34440 & -0.10 & 0.40 & 1.12 & + \\
\hline 91 & 94 & 0.66 & -2.87139 & -2.87010 & 1.29 & 0.81 & 2.29 & + \\
\hline 94 & 96 & 0.73 & 21.28022 & 21.27661 & -3.61 & 0.85 & 2.42 & \\
\hline 96 & 98 & 1.34 & -69.78730 & -69.79333 & -6.03 & 1.16 & 3.27 & \\
\hline 98 & 99 & 0.56 & -23.92936 & -23.91814 & 11.22 & 0.75 & 2.12 & \\
\hline 99 & 100 & 0.65 & -18.64652 & -18.64736 & -0.84 & 0.80 & 2.27 & + \\
\hline 100 & 101 & 0.71 & -14.73366 & -14.73020 & 3.46 & 0.84 & 2.39 & \\
\hline
\end{tabular}


Table 2 Height changes of benchmarks on part of the levelling line.

\begin{tabular}{|c|c|c|c|c|c|c|c|}
\hline \multirow[t]{2}{*}{$\begin{array}{l}\text { Number of } \\
\text { benchmark }\end{array}$} & \multicolumn{2}{|c|}{$\begin{array}{c}\text { Height referenced to relative } \\
\text { stable benchmark } \\
H[\mathrm{~m}]\end{array}$} & \multirow{2}{*}{$\begin{array}{c}\text { Height difference } \\
\text { change between } \\
\text { epochs } \\
\Delta H[\mathrm{~mm}] \\
1948-1975\end{array}$} & \multirow{2}{*}{$\begin{array}{c}\text { RMSE } \\
\text { of height } \\
\text { difference } \\
\text { change } \\
\text { [mm] }\end{array}$} & \multirow{2}{*}{$\begin{array}{c}\text { Double } \\
\text { error of } \\
\text { difference } \\
\text { change } \\
{[\mathrm{mm}]}\end{array}$} & \multirow{2}{*}{$\begin{array}{l}\text { Velocity of } \\
\text { change of } \\
\text { height } \\
\text { V } \\
\text { [mm/year] }\end{array}$} & \multirow[t]{2}{*}{$\begin{array}{c}\text { RMSE of } \\
\text { velocity of } \\
\text { height change } \\
\text { [mm/year] }\end{array}$} \\
\hline & 1948 & 1975 & & & & & \\
\hline 70 & 553.44430 & 553.42568 & -18.62 & 4.79 & 9.59 & -0.69 & 0.18 \\
\hline 71 & 550.51876 & 550.50769 & -11.07 & 4.69 & 9.39 & -0.41 & 0.17 \\
\hline 72 & 528.28837 & 528.27845 & -9.92 & 4.56 & 9.12 & -0.37 & 0.17 \\
\hline 74 & 522.72659 & 522.71508 & -11.51 & 4.15 & 8.30 & -0.43 & 0.15 \\
\hline 75 & 525.11667 & 525.10397 & -12.70 & 4.01 & 8.02 & -0.47 & 0.15 \\
\hline 76 & 524.17221 & 524.15635 & -15.86 & 3.93 & 7.85 & -0.59 & 0.15 \\
\hline 77 & 523.01175 & 522.99477 & -16.98 & 3.80 & 7.60 & -0.63 & 0.14 \\
\hline 78 & 520.39915 & 520.38895 & -10.20 & 3.71 & 7.43 & -0.38 & 0.14 \\
\hline 80 & 541.39781 & 541.39046 & -7.35 & 3.25 & 6.50 & -0.27 & 0.12 \\
\hline 81 & 554.55239 & 554.55040 & -1.99 & 2.88 & 5.76 & -0.07 & 0.11 \\
\hline 84 & 535.02307 & 535.01976 & -3.31 & 1.70 & 3.39 & -0.12 & 0.06 \\
\hline 86 & 529.78208 & 529.77991 & -2.17 & 1.40 & 2.80 & -0.08 & 0.05 \\
\hline 87 & 535.64131 & 535.63775 & -3.56 & 1.20 & 2.40 & -0.13 & 0.04 \\
\hline 90 & 544.61113 & 544.61123 & 0.10 & 0.56 & 1.12 & 0.00 & 0.02 \\
\hline 91 & 545.95563 & 545.95563 & 0.00 & 0.00 & 0.00 & 0.00 & 0.00 \\
\hline 94 & 543.08424 & 543.08553 & 1.29 & 1.15 & 2.29 & 0.05 & 0.04 \\
\hline 96 & 564.36446 & 564.36214 & -2.32 & 1.67 & 3.33 & -0.09 & 0.06 \\
\hline 98 & 494.57716 & 494.56881 & -8.35 & 2.34 & 4.67 & -0.31 & 0.09 \\
\hline 99 & 470.64780 & 470.65067 & 2.87 & 2.57 & 5.13 & 0.11 & 0.10 \\
\hline 100 & 452.00128 & 452.00331 & 2.03 & 2.81 & 5.61 & 0.08 & 0.10 \\
\hline 101 & 437.26762 & 437.27311 & 5.49 & 3.05 & 6.10 & 0.20 & 0.11 \\
\hline
\end{tabular}

Table 1 shows the height differences between benchmarks in two measurement epochs, which formed the basis for the calculation of height difference change between epochs (2). Additionally the associated statistics are calculated: RMSE of height differences (1), double error of height difference - the maximum acceptable error of height differences change (3), and indication of benchmark stability (4). It also indicated stable and unstable height differences in both measurement epochs. Among the analysed values the unchanged height differences were recorded between benchmarks 90-91 and 91-94. For further analysis the stable point number 91 was adopted. Table 1 presents stability of height differences between benchmarks in research period (data obtained from the Land Survey Office of the Czech Republic).

In the next step the height of the benchmarks in two measurement epochs was determined in terms of the reference point number 91. These data are presented in Table 2, which presents the height differences (2), RMSE for determined height (5), double error of determined height, velocities of height change (6) and RMSE of velocities of height change (7). New benchmark heights were calculated as referenced to relative stable point in research epochs.
Significant displacement of benchmarks is marked in bold.

The graphic illustration of the changes of height benchmarks along the levelling lines is shown in Figure 6. Generally it can be stated that the south-west tectonic fault part is subsidence while the north-east tectonic fault part is uplift.

Significant velocities of change of height benchmarks are marked with a dot (Fig. 6). The mean value of these changes is shown in Figure 6 $(-0.3 \mathrm{~mm} /$ year and $-0.1 \mathrm{~mm} /$ year $)$ which concerns the tectonic zone to $3 \mathrm{~km}$ from the tectonic fault.

\section{ACTIVITY OF TECTONIC ZONES IN THE SUDETY MTS.}

Results of these analyses covering the area of the Sudety Mts. are presented in Figure 7. Different directions and values of velocities of benchmarks vertical changes in each tectonic zone in the area under study confirmed the geological block structure of the Sudety Mts. The maximal changes concern the Intrasudetic zone, as well as the area of the PoŕíćíHronov tectonic zone. The most active tectonic zones should include also the area between the towns Králiky and Svitavy along the levelling line EF. Main tectonic faults (Sudetic Marginal fault, Jilovice fault 


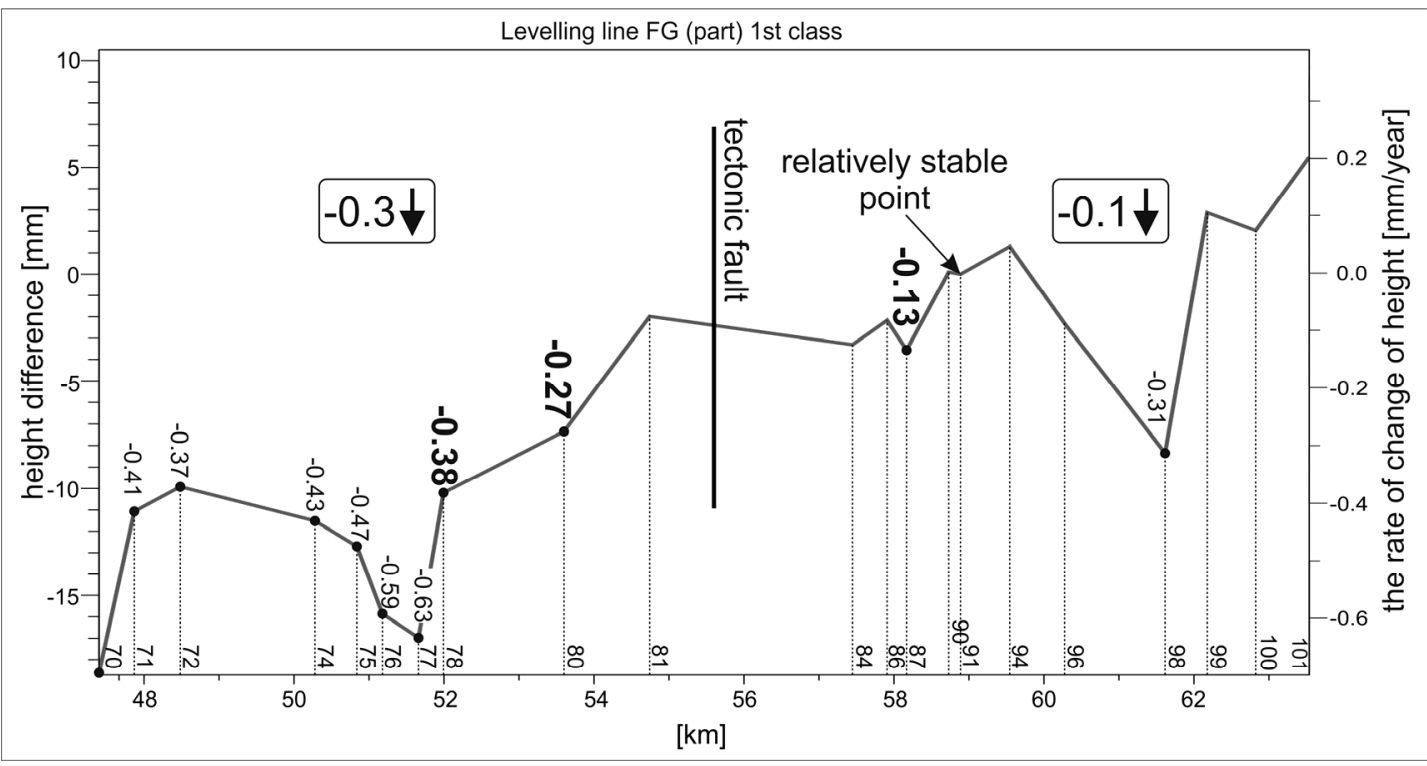

Fig. 6 Height changes of benchmarks and their velocities of height changes.

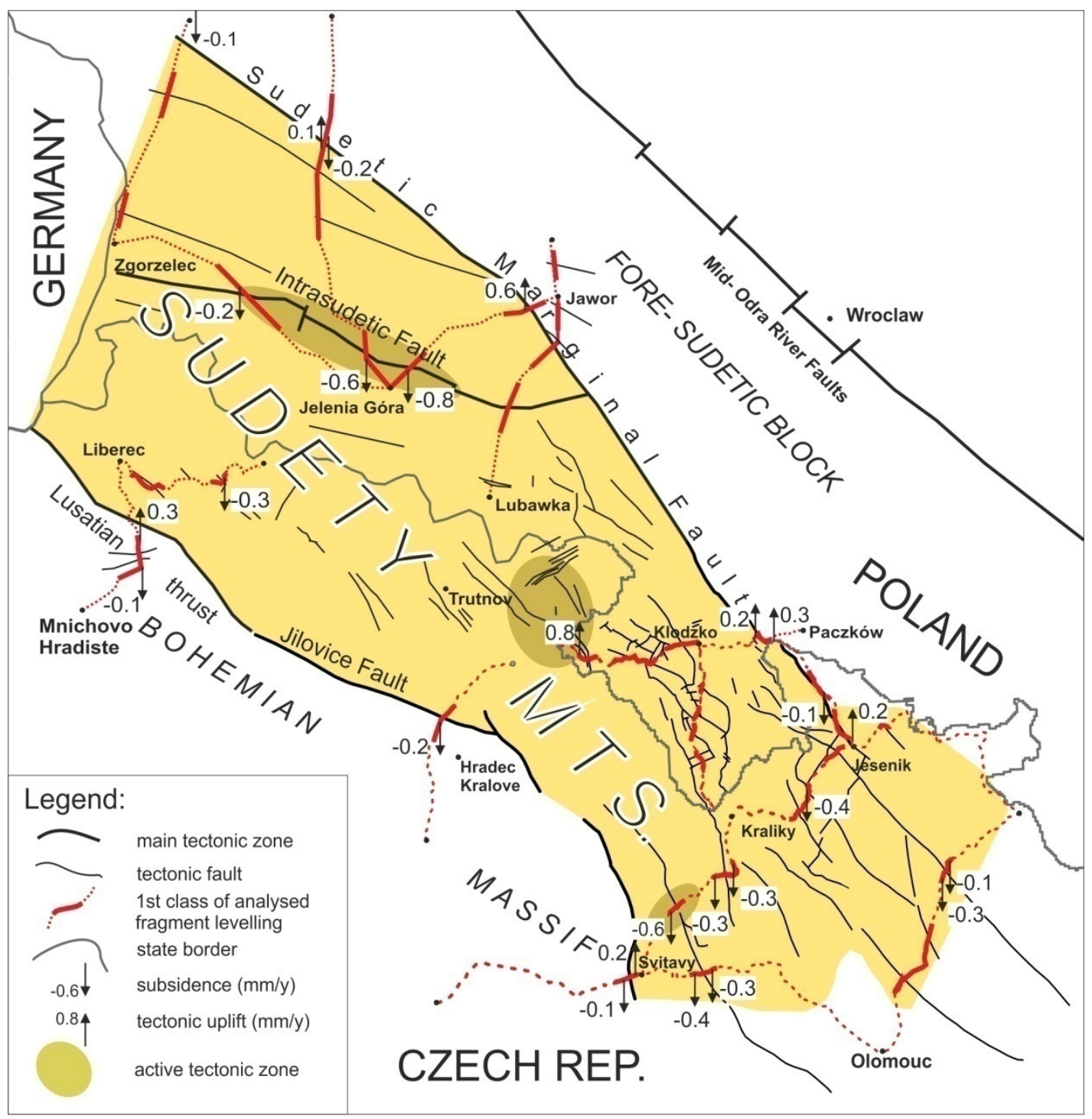

Fig. 7 Vectors directions and values of average velocities of benchmarks vertical movements. 
and Lusatian thrust) which form borders of the Sudety Mts. have low tectonic activity.

\section{CONCLUSION}

The result of research shows the relative vertical movements of the tectonic zones in the Sudety Mts. in the last half-century of the 20th century. This is another verification of the geodynamic mobility of this area. The movements are characterized by values between +0.8 and $-0.8 \mathrm{~mm} /$ year. The largest of them are located in the Intrasudetic zone (Western Sudetes), where the changes indicate subsidence (from -0.2 to $-0.8 \mathrm{~mm} /$ year). In the Eastern Sudetes the largest, positive values of these movements $(+0.8 \mathrm{~mm} /$ year $)$ are located in area of the Poříćí-Hronov tectonic zone. In external geological structures of the Sudety Mts. to the north-east from the Sudetic Marginal fault there are subsidences in its west part up to $-0.2 \mathrm{~mm} /$ year, while the east part tends to uplift $+0.3 \mathrm{~mm} /$ year. On the south-west zone from the border of the Jilovice fault and Lusatian thrust there are movements of subsidence to $-0.2 \mathrm{~mm} /$ year. The presented quantitative values of this research have a cognitive character consistent with the qualitative results of geological research concerned with the geological block structure of the Sudety Mts. The utilitarian research aspect is related to adequate protection of the proposed road infrastructure and modernized transit routes intersections of the mobile Sudetic fault. This involves the possibility of activating tectonic movements and vibration induced by heavy car transport. This also applies to large new engineering investments on the active tectonic faults.

The discussion of the tectonic activity of the Sudety Mts. focused on the analysis of changes of height of each benchmark in the tectonic zones is a further step in the research of recent geological activity of this area. It is reasonable also to extend the analysis for repeated measurements of the levelling lines of $2^{\text {nd }}$ order. Results of previous research and their extent may be the basis for detailed interpretation of the geological block structure of the Sudety Mts.

\section{ACKNOWLEDGMENTS}

The archival data of repeated measurement levelling lines were obtained from the Central Office Documentation Geodesy and Cartography in Warsaw (Poland) and the Land Survey Office of the Czech Republic. The research was supported by project $\mathrm{CZ}$ 1.05/2.1.00/03.0097 - regional centre "AdMAS".

\section{REFERENCES}

Cacoń, S., Kapłon, J., Kontny, B., Weigel, J., Švábenský, O. and Kopecký, J.: 2010, Recent local geodynamics in the central part of the Stolowe Mts. Acta Geodyn. Geomater., 7, No. 3 (159), 335-342.

Cacoń, S., Švábenský, O., Kontny, B., Weigel, J., Jamroz, O., Ćmielewski, K., Bosy, J., Kapłon, J. and Machotka, R.: 2004, Deformation analysis of the upper part of the Earth crust in the Snieznik Massif (Polish and Czech sides between 1993 and 2003). Acta Geodyn. Geomater., 1, No. 3 (135), 59-67.

Jechumtálová, Z. and Šílený, J.: 2014, Seismic loading of the Industrial Zone Triangle. Department of Seismology, Institute of Geophysics, Academy of Sciences, Prague.

Kapłon, J. and Cacon, S.: 2009, Research on the marginal Sudetic fault activity with use of GPS and precise levelling techniques. Acta Geodyn. Geomater., 6, No. 3, 323-329.

Kapłon, J., Kontny, B., Grzempowski, P., Schenk, V., Schenkova, Z., Balek, J. and Holesovsky, J.: 2014, GEOSUD/SUDETEN network GPS data reprocessing and horizontal site velocity estimation. Acta Geodyn. Geomater., 11, No. 1 (173), 65-75.

DOI: 10.13168/AGG.2013.0058

Kontny, B.: 2003, Geodetic research of contemporary kinematics of the main tectonic structures of the Polish Sudetes and the Fore-Sudetic Block with the use of GPS measurement. Scientific papers of the Agricultural University of Wroclaw, $468 \mathrm{pp}$, dissertation, CCII.

Kowalczyk, K.: 2006, Modelling of the vertical movements of the Earth's crust with the help of the collocation method. 8th Bilateral Poland-Italy Geodetic Meeting, Wroclaw. 22-24 June, 2006.

Procházková, D.: 1989, Weak earthquake of Aug. 10, 1987 connected with the Jílovice fault (Northern Bohemia). Studia Geoph. Geod, 33, No. 1, 97-100. DOI: 10.1007/BF01649634

Schenk, V., Schenkova, Z., Cacoń, S., Kontny, B., Bosy, J. and Kottnauer, P.: 2003, To geodynamic interpretations of GPS data monitored on the East Sudeten network. Acta Montana, Ser. A, Geodynamics, No. 24 (131), 87-97.

Stupnicka, E.: 2007, Polish regional geology, revised third edition. University of Warsaw, Warsaw, (in Polish).

Vanko, J. and Vyskočil, P.: 1987, The map of vertical crustal movements in Czechoslovakia. Journal of Geodynamics, 8, 143-150. DOI: $10.1016 / 0264 \_3707(87) 90032-9$

Vyskočil, P.: 2002, Vertical movements at the territory of Karkonose-Jeseniky Mts, first estimation. Acta Montana, 20, 124, 119-123.

Wyrzykowski, T.: 1985, Map of recent absolute vertical velocities of movement the surface of the Earth's crust in the Polish area on scale 1:2500000. Institute Geodesy and Cartography, Warsaw, (in Polish).

Wyrzykowski, T.: 1993, The use of precision levelling to designate recent vertical movements of the Earth's crust and the impact of these movements on leveling. In: Precise levelling: geometric levelling, trigonometric levelling, satellite levelling and hydro levelling, Ed. Laudyn, I.,II, PPWK, Warsaw, 725-764, (in Polish).

Zedník, J., Pospišil, J., Růžek, B., Horálek, J., Boušková, A. and Jedlička, P.: 2001, Earthquakes in the Czech Republic and surrounding regions in 1995-1999. Studia Geoph. Geod., 45, 267-282. DOI: $10.1023 /$ A.102208412758 